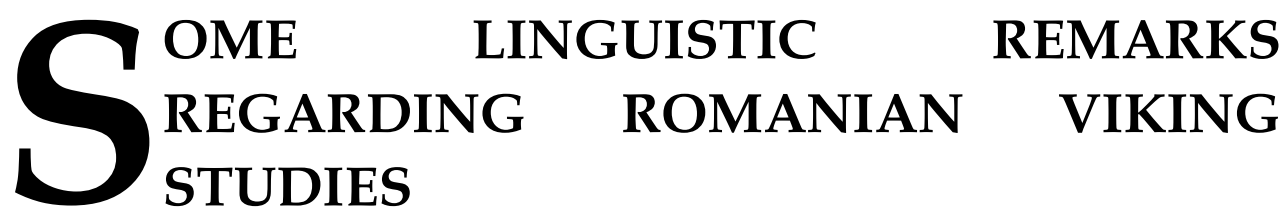

\section{Costel Coroban}

Valahia University of Târgovişte \& Ovidius University of Constanța, Email: coroban.costel@gmail.com

\section{Acknowledgments}

This paper has been presented at the Fourth International Conference on Nordic and Baltic Studies „Empire-building and Region-building in the Baltic, North and Black Sea Areas”, in Constanta, Romania, May 24-26, 2013.

\begin{abstract}
:
In Romania there is no academic program dedicated entirely to the study of the Viking period in Scandinavia and Europe, but Romanian historiography can still boast with a decent number of monographs, translations and studies relating to early medieval Northern Europe. The concern of the present study is that of offering a general view on the language variations used by Romanian historians or translators when referring to certain Viking historical characters, rituals, artefacts or any other aspects regarding the history of the Norsemen. One of the first terms that ought to be considered by this study is the Old Norse word "viking" (used in runic inscriptions in contexts such as the verbal group "fara i viking" - meaning "to go on a raid", "to go a-viking"). The complexity of translating this verbal structure into Romanian comes from the difficulty of turning the borrowed ethnonym "Viking" into a verbal phrase. Thus, it has been rendered as "a merge in expeditie vikingă"/"going on a Viking [+fem. desinence] expedition". The only downside of using this phrase is that it might imply pleonasm since the Romanian noun "viking" already refers to raids and seafaring activities. Other authors have instead proposed the translation of "cineva care face un inconjur"/"somebody who goes on an expedition", or simply "care e departe de casă"/"someone away from home". But a royal saga also tells us about a noble who was "stundum i kaupferdum en stundum í vikingu" which is translated into Romanian as "în acelaşi timp $\hat{\imath}$ călătorie de afaceri şi în expediție vikingă [at the same time in business trip and in viking expedition]". The translation of i viking as "a merge in expeditie viking [going on a viking expedition]" also appears. In the translation of Frans G. Bengtsson's well know The Long Ships, going a-viking is translated into Romanian as "seceriş [reaping], incursiune de jaf [raid for plundering]", which is interestingly
\end{abstract}


the only identifiable metaphor for this activity. Vikings also rarely appear as "wikingi" instead of the very common "vikingi" in Romanian translations.

\section{Rezumat:}

În România nu există niciun program academic dedicat integral studiului perioadei vikinge în Scandinavia şi Europa, dar istoriografia românească se poate lăuda cu un număr cel puțin decent de monografii, traduceri şi studii despre nordul Europei la începutul Evului Mediu. Studiul de față doreşte să ofere o imagine generală asupra variațiilor de lexic din lucrările istorice româneşti sau din traducerile ce fac referire la istoria vikingilor sau la anumite personalități ori ritualuri, artefacte sau orice alte aspecte legate de istoria oamenilor nordului. Unul din primii termeni ce ar trebui luați în considerare este cuvântul "viking" din limba nordică veche (folosit în inscripții runice cum ar fi grupul verbal "fara í víking" - însemnând "a merge intrun raid", sau forțat din punct de vedere gramatical şi lexical, "a merge in vikingie”). Complexitatea traducerii acestei structuri verbale în limba română vine din dificultatea transformării etnonimului imprumutat "viking" într-o structură verbală. Aşadar, a fost tradus ca "a merge in expediție vikingă". O problemă a constitui-o conotație cuvântului "viking" în limba română, care deja include sensul de activitate de raid pe mare sau pe uscat, astfel că "expeditie vikingă" poate constitui un pleonasm. Alți autori au folosit in schimb traducerea de "cineva care face un inconjur", sau, mai simplu, "cineva care e departe de casă". O saga regală ne pomeneşte despre un nobil care era "stundum í kaupferdum en stundum í víkingu", ,, in acelaşi timp în călătorie de afaceri şi în expediție vikingă". Traducerea lui "í viking" ca "a merge în expediție viking" apare de asemenea (se observă, aici, lipsa desinenței de feminin $\hat{\imath}$ formula "expediție viking"). In traducerea binecunoscutului roman al lui Frans G. Bengtsson în limba română, a merge în expediție vikingă este tradus ca "seceriş, incursiune de jaf", ceea ce reprezintă singura metaforă identificabilă pentru aceste termen. Demonimul "vikingi" mai apare în mod rar şi $c a$ "wikingi" $\hat{\imath}$ loc de varianta anterioară foarte răspândită, cu $" v "$.

Keywords: Viking studies, Romania, translations, Edda, Old Norse

Although in Romania there is no academic program dedicated entirely to the study of the Viking period in Scandinavia and Europe, Romanian historiography can boast with a decent number of monographs, translations and studies relating to early medieval Northern Europe. The concern of the present study is that of offering a general view on the language variations used by Romanian historians or translators when referring to certain Viking historical characters, rituals, artifacts or any other aspects regarding the history of the Norsemen. One of the first 
terms that ought to be considered by this study is the Old Norse word "viking" (used in runic inscriptions in contexts such as the verbal group "fara i víking" - meaning "to go on a raid", "to go a-viking"). The complexity of translating this verbal structure into Romanian comes from the difficulty of turning the borrowed ethnonym "Viking" into a verbal phrase. Thus, it has been rendered as "a merge in expeditie vikingă" /"going on a Viking [feminine desinence] expedition". It appears so in the translation of the beautifully alliterating expression "a vestrsvegum i vikingu, pe drumul de apus în expediție vikingă [on the western road in viking.fem expedition]" 1 . The only downside of using this phrase is that it might imply pleonasm since the Romanian noun "viking" already refers to raids and seafaring activities. Other authors have instead proposed the translation of "cineva care face un înconjur" /"somebody who goes on an expedition", or simply "care e departe de casă" /"someone away from home". But a royal saga also tells us about a noble who was "stundum i kaupferdum en stundum i vikingu" which is translated into Romanian as "în acelaşi timp în călătorie de afaceri şi în expediție vikingă [at the same time in business trip and in viking expedition]"2. The translation of $i$ víking as "a merge în expediție viking [going on a viking expedition]" 3 also appears. In the translation of Frans G. Bengtsson's well know The Long Ships, going a-viking is translated into Romanian as "seceriş [reaping], incursiune de jaf [raid for plundering]", which is interestingly the only identifiable metaphor for this activity ${ }^{4}$ Vikings also rarely appear as "wikingi" instead of the very common "vikingi" in Romanian translations.

The study of such linguistic variations as presented above is both interesting and useful, especially for those who would approach the Viking era in writing both academic works and works for the general public in Romania.

The body of the following article will mostly be concerned with the exposition of the various linguistic choices made by Romanian translators or historians of Old Norse history or literature. The exact

\footnotetext{
${ }^{1}$ Frédéric Durand, Vikingii (Corint: Bucureşti, 2003), translation Ovidiu Cristea, 24.

2 Régis Boyer, Islanda medievală. Vikingii (ALL: Bucureşti, 2002), 82.

3 Boyer, 2002, 55.

4 Frans G. Bengtsson, Vikingii. O povestire istorică din vremurile străbune, traducere de Constantin A. Gâdei (Dacia: Cluj, 1974), 5.
} 
English equivalent will be given in square brackets immediately after the Romanian text. More background information from universal historiography regarding the discussed concepts is to be found in footnotes.

One of the first works taken in consideration for such a purpose should be the Eddas. In fact, concerning religion and rites, I have given most deference to the translated Edda than to other works, as the default source for Viking mythology. Concerning mythology, translation variations from other Romanian sources dealing with the Vikings are only mentioned if they are different than the Edda. Another argument for this is that the Edda has also been translated relatively recently (2005). Others may argue that Valhalla şi Thule 5 should be the standard comparison work, but considering that it has been published in a time when loan words were not preffered over quite forcefull native equivalents, the translated Edda still remains the preferred choice.

Masterpieces of Scandinavian culture, the Eddas contain a lot of lore regarding all the aspects of the Old Norse religion and society. These very important writings have been translated from German ${ }^{6}$ by Magda Petculescu in a - otherwise quite late but very welcome - 2005 edition. ${ }^{7}$ The volume includes both the Poetic Edda and the Prose Edda. The former is referred to as "Edda poetică [Poetic Edda]", "Edda cea veche [Elder Edda]" or "Edda lui Saemunda [Saemunda's Edda]". The latter is called "Edda în prozăa", "Edda cea nouă [New Edda]" or "Snorra Edda".

For the present study even the table of contents of the translated Edda contains valuable insight. The titles of the Elder Edda contain many noun-noun compound words. Their translation has been done as follows.

\footnotetext{
${ }_{5}^{5}$ Walhalla şi Thule. Mituri şi legende vechi germanice, vol. 1, vol. 2, retelling by Mihai Isbăşescu (Editura Minerva: Bucureşti, 1977).

${ }^{6}$ From Die Edda. Die Lieder der sogenannten älteren Edda nebst einem Anhang: Die mythischen und heroischen Erzählungen der Snorra Edda, übersetzt und erläutert von Hugo Gering, Leipzig und Wien, Bibliographisches Institut, 1895.

${ }^{7}$ EDDA, translation by Magda Petculescu, foreword by Dan Grigorescu (Bucureşti: Saeculum I.O., 2005).

8 The version "Edda cântecelor [Songs' Edda]" may also be found in Walhalla şi Thule.

9 The version „Edda prozaică [Prose Edda]" may also be found in Walhalla şi Thule.
}

122 
"Spq" is translated as "proroocire [prophecy]" (in case of Voluspó10) as well as "prezicere [prediction]" (in the case of Grípisspó'11).

"Vipa," "mọl" and "ljóp" all appear as "cânt [canto]". For example, Prymskvipa is translated as "Cântul lui Thrym [Thrym's canto/song]", where the Romanization of the Thurs $(\mathrm{P} / \mathrm{p})$ rune is evident (the non-Romanized Old Norse names of the songs are also given in brackets). Otherwise they are differentiated in meaning: vipa = lay (sung poem); mọ́l = ballad; ljóp = poem. In the Romanian translation, the exception is Họvamọl which is translated as "Proverbele lui Har [Har's Proverbs]" and Hymiskvipa which is translated as "cântecul [the song]" instead of "canto". As noticed below, in English translation Họvamọ́l appears as The Ballad of the High One. In Islanda medievală, "Vipa," "mól" and "ljóp" are translated as "narative poem”, ,zise [medieval sayings]" and "medieval poem"12 which is closer to their original meanings.

\begin{tabular}{|c|c|c|}
\hline $\begin{array}{l}\text { Romanian } \\
\text { translation } \\
\text { [English, where it } \\
\text { differs] }\end{array}$ & English translation & Old Norse original \\
\hline $\begin{array}{l}\text { Prezicerea } \\
\text { vizionarei [The } \\
\text { Visionary } \\
\text { Woman's } \\
\text { Prediction] }\end{array}$ & $\begin{array}{l}\text { The Wise-Woman's } \\
\text { Prophecy }\end{array}$ & Voluspó \\
\hline Visele lui Baldr & Baldr's Dreams & Baldrs Draumar \\
\hline Cântul lui Thrym & The Lay of Thrym & Prymskvipa \\
\hline $\begin{array}{l}\text { Cântecul } \begin{array}{l}\text { lui } \\
\text { Hymir } \\
\text { Song] }\end{array} \\
\text { Hymir's }\end{array}$ & The Lay of Hymir & Hymiskvipa \\
\hline $\begin{array}{l}\text { Cuvintele de harță } \\
\text { ale lui Loki }\end{array}$ & Loki's Wrangling & Lokasenna \\
\hline Cântul lui Harbard & $\begin{array}{l}\text { The Poem } \\
\text { Harbarth }\end{array}$ & Hárbarpsljóp \\
\hline
\end{tabular}

\footnotetext{
10 The Wise-Woman's Prophecy is the first poem of the Elder Edda, see Henry Adams Bellows, The Poetic Edda (1936). This English translation is taken as reference for the current analysis. 11 Gripir's Prophecy, see Henry Adams Bellows' translation.

12 Boyer, 2002, 176.
} 


\begin{tabular}{|c|c|c|}
\hline Cântul lui Skirnir & $\begin{array}{l}\text { The Ballad of } \\
\text { Skirnir }\end{array}$ & Skírnis mọ́l \\
\hline $\begin{array}{ll}\text { Cântul } & \text { lui } \\
\text { Wafrhtudnir }\end{array}$ & $\begin{array}{l}\text { The Ballad of } \\
\text { Vafthruthnir }\end{array}$ & Vafprúthnismọl \\
\hline Cântul lui Grminir & $\begin{array}{l}\text { The Ballad of } \\
\text { Grimnir }\end{array}$ & Grimnismọ́l \\
\hline Cântul lui Alwis & The Ballad of Alvis & Alvíssmǫl \\
\hline $\begin{array}{l}\text { Proverbele lui Har } \\
\text { [Har's Proverbs] }\end{array}$ & $\begin{array}{l}\text { The Ballad of the } \\
\text { High One }\end{array}$ & Hǫvamọ́l \\
\hline Cântul lui Rig & The Song of Rig & Rígspula \\
\hline Cântul Hyndlei & $\begin{array}{l}\text { The Poem of } \\
\text { Hyndla }\end{array}$ & Hyndluljóp \\
\hline $\begin{array}{ll}\text { Cântul } & \text { lui } \\
\text { Swipdag } & \end{array}$ & $\begin{array}{l}\text { The Ballad of } \\
\text { Svipdag }\end{array}$ & Svipdagsmọl \\
\hline Cântul lui Wolund & The Lay of Völund & Vólundarkvipa \\
\hline $\begin{array}{l}\text { Cântul lui Helgi, } \\
\text { fiul lui Hjorward }\end{array}$ & $\begin{array}{l}\text { The Lay of Helgi the } \\
\text { Son of Hjorvarth }\end{array}$ & $\begin{array}{l}\text { Helgakvipa } \\
\text { Hjorvarthssonar }\end{array}$ \\
\hline $\begin{array}{l}\text { Primul cânt despre } \\
\text { Helgi, omorâtorul } \\
\text { lui Hunding }\end{array}$ & $\begin{array}{l}\text { The First Lay of } \\
\text { Helgi } \\
\text { Hundingsbane }\end{array}$ & $\begin{array}{l}\text { Helgakvipa } \\
\text { Hundingsbana I }\end{array}$ \\
\hline $\begin{array}{lr}\text { Cel de al doilea } \\
\text { cânt despre Helgi, } \\
\text { ucigaşul } & \text { lui } \\
\text { Hunding } & \\
\end{array}$ & $\begin{array}{l}\text { The Second Lay of } \\
\text { Helgi } \\
\text { Hundingsbane }\end{array}$ & $\begin{array}{l}\text { Helgakvipa } \\
\text { Hundingsbana II }\end{array}$ \\
\hline $\begin{array}{l}\text { Moartea } \\
\text { Sinfjotli }\end{array}$ & Of Sinfjotli's Death & Frá Dauða Sinfjǫtla \\
\hline $\begin{array}{l}\text { Proroocirea lui } \\
\text { Gripir }\end{array}$ & Gripir's Prophecy & Grípisspó \\
\hline Cântul lui Regin & The Ballad of Regin & Reginsmọil \\
\hline Cântul lui Fafnir & The Ballad of Fafnir & Fáfnismọ́l \\
\hline Cântul Sigrdrifei & $\begin{array}{l}\text { The Ballad of The } \\
\text { Victory-Bringer }\end{array}$ & Sigrdrifumọ́l \\
\hline $\begin{array}{l}\text { Fragment dintr-un } \\
\text { cânt al lui Sigurd }\end{array}$ & $\begin{array}{l}\text { Fragment of a } \\
\text { Sigurth Lay }\end{array}$ & $\begin{array}{l}\text { Brot } \\
\text { Sigurparkvipu }\end{array}$ \\
\hline $\begin{array}{l}\text { Primul cânt al } \\
\text { Gudrunei }\end{array}$ & $\begin{array}{l}\text { The First Lay of } \\
\text { Guthrun }\end{array}$ & Guprúnarkvipa I \\
\hline
\end{tabular}




\begin{tabular}{|c|c|c|}
\hline $\begin{array}{l}\text { Cântul cel scurt al } \\
\text { lui Sigurd }\end{array}$ & $\begin{array}{l}\text { The Short Lay of } \\
\text { Sigurth }\end{array}$ & $\begin{array}{l}\text { Sigurparkvipa en } \\
\text { Skamma }\end{array}$ \\
\hline $\begin{array}{lr}\text { Călătoria } & \text { spre } \\
\text { moarte } & \text { a } \\
\text { Brynhildei } & \end{array}$ & $\begin{array}{l}\text { Brynhild's Hell- } \\
\text { Ride }\end{array}$ & Helreip Brynhildar \\
\hline $\begin{array}{l}\text { Dispariția } \\
\text { Niflungilor }\end{array}$ & $\begin{array}{l}\text { The Slaying of The } \\
\text { Niflungs }\end{array}$ & Dráp Niflunga \\
\hline $\begin{array}{l}\text { Cel de al doilea } \\
\text { cântec al Gudrunei }\end{array}$ & $\begin{array}{l}\text { The Second, or Old, } \\
\text { Lay of Guthrun }\end{array}$ & $\begin{array}{l}\text { Guprúnarkvipa } \\
\text { ónnur }\end{array}$ \\
\hline $\begin{array}{l}\text { Cel de al treilea } \\
\text { cântec al Gudrunei }\end{array}$ & $\begin{array}{l}\text { The Third Lay of } \\
\text { Guthrun }\end{array}$ & $\begin{array}{l}\text { Guthrúnarkvipa en } \\
\text { pripja }\end{array}$ \\
\hline $\begin{array}{l}\text { Cântecul de jale al } \\
\text { Oddrunei }\end{array}$ & $\begin{array}{l}\text { The Lament of } \\
\text { Oddrun }\end{array}$ & Oddrúnargrátr \\
\hline Cântul lui Atli & $\begin{array}{l}\text { The Greenland Lay } \\
\text { of Atli }\end{array}$ & Atlakvipa \\
\hline $\begin{array}{l}\text { Cântecul } \\
\text { groenlandez al lui } \\
\text { Atli }\end{array}$ & $\begin{array}{l}\text { The Greenland } \\
\text { Ballad of Atli }\end{array}$ & $\begin{array}{l}\text { Atlamọl } \\
\text { Grœnlenzku }\end{array}$ \\
\hline $\begin{array}{l}\text { Instigarea } \\
\text { Gudrunei }\end{array}$ & $\begin{array}{l}\text { The Lament of } \\
\text { Oddrun }\end{array}$ & Gupránarhvǫt \\
\hline Cântul lui Hamdir & $\begin{array}{l}\text { The Ballad } \\
\text { Hamther) }\end{array}$ & npismọ́l \\
\hline
\end{tabular}

It is interesting that in the Foreword of the Edda written by Acad. Dan Grigorescu, the skalds are referred to as "virtuozi ai poeziei curtene [virtuosos of court poetry]"13. Reference is made to "poemele «de scuturi» [the «shield» poems]", as descriptions of the mythological symbols engraved on the shields of the warriors. ${ }^{14}$

Regarding the contents of the Edda, it is worth noticing the variations of the name of Odin, which are plentiful in the Viking lore. ${ }^{15}$ In the beginning of Voluspó, Odin is referred to as „părintele care alege [the

\footnotetext{
13 EDDA, 7.

14 Ibid., 7-8.

15 A few of his "nicknames" are All-Father, The Useful Adviser, The Rover, The LongBearded, The Serpent, Lord of the Gallows, Ill-doer, Terrifier, Father of Victory, One-Eye, Raven-God, Mimir's Friend, Fenrir'r Foe, The High One, The Wise in Beguiling, The Feared One (according to professor Sally Vaugh, University of Houston).
} 
father who chooses]"16 and later as "furtunosul [the stormy one]"17, "Hawi - cel mare [the great one]", "cel de două ori [the double one]"18, "părintele spânzuraților [the father of the hanged ones]", "bătrânul creator [the old creator]", "Widrir, Tunătorul [the Thundering One]", "Sidgrani, barbălungă [long beard]", "Hars, cel măreț [the great one]" or as Hropt, Gagnrad, Ydd, Thund, "Ragna-Hropt, zeul zeilor" [the god of all gods], "Hroptatyr", Herjan, "Sigtyr, zeul victorios [Sigtyr, the victorious god]", Fjorgyn; Allvata, Părintele atoate [Allfather] but also „Alfadar [Allfather?]”, Wotan, ,părintele luptei ${ }^{19}$, cel voios la arme [father of the battle, the weapon-eager one]" 20, "Wotan, Wodan sau Odin ... furiosul, cel care mugeşte [the furios one, the roaring one]", ,"Asul suprem [the supreme Asen]" or "Marele Magician [the great magician]”, ,Marele Bărbat/Părinte al Armatelor [the great man/parent of the armies]"21. Vé, the brother of Odin and Vili, also appears as "Vû" 22, Vili as Vile23. Odin is sometimes also called Oden ${ }^{24}$.

Heimdall is referred to as "cel ce străluceşte peste toată lumea [the one shining over the entire world]" or "păzitorul zeilor [the guardian of the gods]", "cel ce străluceşte peste lume [the one shining over the world]"25, or "Zeul Alb [The White God]"26. Baldr (also Balder, Baldur 27) appears as "Stăpânul [The Master]"28, Loki as "cel ce închide, cel ce termină [the one who closes, the one who finishes]" but reference is also made to "Logi, vâlvătaia [Logi, the flame]", "stăpânul focos al vâvătăii învolburate [the fiery master of the whirling blaze]"29. Loki also appears as "Loke, Gudaspllitrare, cel care dezbină zeii [the one who disunites the

\footnotetext{
16 EDDA, 35.

17 Ibid., 38.

18 Ibid., 46.

19 In the translation of Beowulf, "părintele luptei” is translated using the biblical "Savaot/Sabaoth" (sic!).

20 Cornelia Belcin, Alexandru Popescu, Vikingii (Albatros: Bucureşti, 1976), 136.

21 Baedeker, 2006, 229.

22 Cristina Jinga, Comorile nibelungilor (Prietenii Cărții: Bucureşti, 2003), 167, 54.

${ }_{23}^{3}$ Mitologia nordică, 8.

${ }^{24}$ Elena-Maria Morogan, Mitologia Nordică. Mituri şi legende (Editura Enciclopedică: Bucureşti, 1992).

25 Walhalla şi Thule vol. 1, 213.

${ }_{26}$ Morogan, 1992, 29.

27 Walhalla şi Thule vol. 1, 191.

28 Boyer, 2002, 122.

29 Walhalla şi Thule vol. 1, 228. 
gods]" or "Şiretul [The Cunning]"30. Frigg as "cea mult iubită, nevasta [the beloved one, the wife], the giant Slidr as "cel dăunător, cel rău [the noxious one, the evil one]". Thor/Tor ${ }^{31}$ as "Wingthor", "cel care aruncă [the throwing one]" or "cel care aruncă învârtind [the one who throws twisting]", "stăpânul de corabie [shipmaster]", "păvaza oamenilor" [ men's aegis], "ucigaşul şarpelui [snake slayer]" or simply "tunetul [the thunder]" or "Asathor". Unsurely, he is also referred to as "Furiosul [The Furious One]" or "neînvinsul [invincible]"32. Freya is also mentioned as "Stăpână [The Lady Master]" but also "Doamna [Lady]"33 and similarly Freyr appears as "the Master" in Romanian. War is considered "zeița făgăduielilor solemne [the goddess of solemn oaths]" and Tyr appears as the god of war in the translated Hymiskvipa, in Walhalla şi Thule other variations of Tyr's name are Tiu, Ziu, Tiwas, Thingsus, Cheru, Saxnot. Curiously, one source refers to Tyr's name in the feminine gender ${ }^{34}$. The significance of Hymir's name is translated into Romanian as "Intunecatul [the Dark One]”. Ægir appears as Ägir. Loki is also referred to as „Lopt, aerul [Lopt, the air]”. Ratatosk is translated as "dinte de rozător/şobolan [rat's/rodent's tooth]" 35 .

Regarding miraculous artifacts, Thor's hammer - which wards off the cross and is a symbol of the Old Norse belief - appears as "Mjolnir, măciuca lui Thor [Mjolnir, Thor's mace]”, "Mjölnir, Zdrobitorul [Crusher]"36, "topor [axe]"37, or „Mjölner ciocanul [the Hammer]"38; The ring Draupnir is interpreted as "picurătorul [the dropper]". Sleipnir, Odin's eight-legged horse's name is translated as „cel care lunecă iute pe deasupra [the one who glides quickly over]"39. Mimir, the giant guardian, appears as "memorie [memory]" and Huginn and Munninn appear as "Gândul şi Aducerea-aminte [Thought and Remembrance]"40.

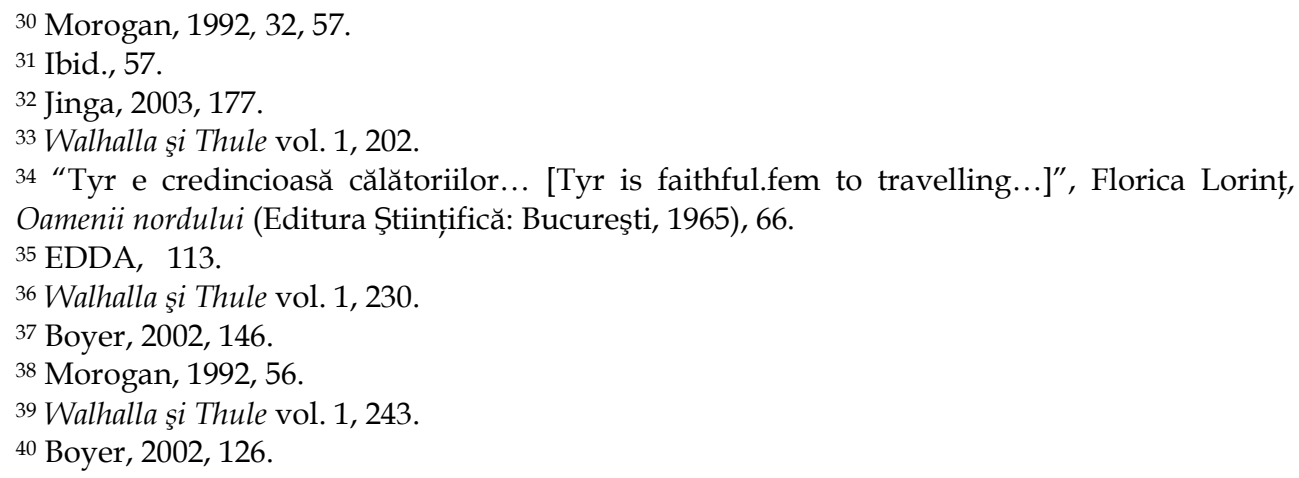


Prymr, the king of the ice giants (jotnar), is called "Thrym", "Zgomotosul [The Noisy/Loud One]". It is quite surprising that the giants are referred to as "Thurşi" in the Romanian translation of Prymskvipa, where Prymr steals Thor's hammer and demands that the goddess Freyja marries him as ransom for the weapon.

Ginnungagap, the primordial void is translated as "hău căscat [yawning chasm]" or "hăul ce se cască [the yawning chasm]"41. Many similar miraculous locations or characters are translated as well: Idafield"2 appears as "câmpia activității neîntrerupte [the field of uninterrupted activity]"; the æsir are referred to as "aseni", "aşi" 43 while the vanir are called "wani"; for the Norns (Fates) the phrase "cele trei, cele mai puternice fete [the three, the strongest girls]" 44 , dwarf appears as "pitic" (although the Romanian borrowed word "gnom" might have been more appropriate); Ask and Embla are translated in a footnote as "frasinul şi ulmul [the ash tree and the elm]", Embla also appears as "un curmei de viță [a sprig of vine]"45; the valkyries appear as "walkirii"46 or even "walküră (singular)" (with the Germanic umlaut and the Romanian schwa in the same word - sic!), "walchirie" 47 , "cea care alege morții [the one choosing the dead]"48. Yggdrasil is also interpreted as "Frasinul lumii [the world's ash tree]" 49 .

The Elves are referred to as "Elbi" or "Alvi" 50 which is interesting and unexpected; in other sources they are mistaken for dwarves when referred to as "alben", but the same source also calls them "elfi [evles]" in other situations ${ }^{51}$. The confusion between Elves and Dwarves in Romanian translations is not uncommon ${ }^{52}$. This is perhaps due to the fact

\footnotetext{
${ }^{41}$ Walhalla şi Thule vol. 1, 205.

42 Situated at the center of Asgard, it was built by Odin in the beginning before giving counsel to the Aesir for the building of the rest of Asgard.

43 Baedeker, 2006, 227.

44 EDDA, 36.

45 Boyer, 2002, 131.

46 Ibid., 2002, 119.

47 Walhalla şi Thule vol. 1, 253.

48 Jinga, 2003, 165.

49 Walhalla şi Thule vol. 1, 202.

50 Morogan, 1992, 67.

51 Walhalla şi Thule vol. 1, 188.

52 It is not only found in Romanian Norse studies. According to many scholars, the kinship between elves and dwarves is troublesome and evident in the elfish names of some dwarves: Alberich (king of the elves), Álfr (elf).
}

128 
that there is no equivalent for Elf in Romanian folklore. In the translation of Beowulf, Elves appear as "iele [virgin fairies, nymphs]". Similarly, the Romanian translation of Beowulf also identifies the monster Grendel to these autochthonous antagonists "căpcăun [ogre]", "hiară [beast /archaism/]", "proclet [cursed one]', "vidma din iad [hellspawn]", "ogru", "bală [hideous beast]"; more so, the various Danish princes in Beowulf's translation and leaders are called voivodes, a term which is of unquestionable local origin.

Otherwise, elves are probably translated as "spirite [spirits]" 53 , but this is hard to prove if the text is not a standard text, such as a saga or a stanza of the Eddas. The expression "elven mill" (used in relation to Álfablót, the sacrifice to the Elves) appears as "morile elfelor [the elven / fem. adj./ mills]". The fact that Elves are perceived as feminine entities is perhaps another clue of interpreting them as the equivalents of Romanian "iele [nymphs]". Curiously, in Islanda medievală, it is stated in the glossary that álfr should not be confused with "the elves of romantic fairy tales", but rather understood as ambiguous supernatural beings equal to the gods and reigning over mental faculties ${ }^{54}$. It is probable that this exigency of the original author, Régis Boyer, is that of drawing a line between the early modern identification of elves with fairies and their quite sinister portrayal in Norse mythology. A very good distinction between Elves, Dwarves, Gnomes, Kobolds and Fairies is drawn in Comorile Nibelungilor, 55 where they are called air spirits and included in the same category as Valkyries, Salamanders and Gnomes (sic!). Water spirits are called "spiriduşii numiți Nixe [the leprachauns/spirits called Nixes]", while Ran, the goddess of the sea, is referred to as "Răpitoarea [kidnapper]" 56. Dísir are also mentioned but only briefly as "disele", destiny-controlling feminine deities ${ }^{57}$.

The draugar, the undead, interestingly appear as "mort-care-nua-murit-cum-trebuie [a dead man who has not died properly]". A draugr is also identified with the Romanian folk term "moroi"58, which

\footnotetext{
53 Cf. Belcin, Popescu, 1976, 134.

54 Boyer, 2002, 258.

55 Jinga, 2003, 34. Also see Cântecul nibelungilor, told by Adrian Maniu (Editura de Stat pentru Literatură şi Artă: Bucureşti, 1958).

56 Ibid. 14.

57 Boyer, 2002, 258.

58 Ibid., 108.
} 
designates the spirit of a dead person who has returned to haunt the living.

Fenrir appears as "copilul uriaşului [the child of the giant]"; Niflhel appears as "iadul încețoşat [the foggy hell]" or "hăul cel mai din străfund [the deepest abyss]"59. The Eliwagar - the ice waves of the Ginnugagap - are referred to as "talazuri uriaşe [huge billows]" but also "talazuri furtunoase [stormy billows]". Asgard is described as "locuința cerească a zeilor [the heavenly abode of the gods]" 60 . Jörmungandr, the Midgard Snake is referred to simply as "şarpele Midgard [the Midgard snake]". Myrkwid, the border to Múspellsheimr, appears as "pădurea cea întunecoasă [the dark forest]". Fenrir is sometimes simply called "Lupul [the wolf]". The Berserkers, warriors who entered into battle in a mindless rage, are named "războinicii fioroşi [fierce warriors]" or even "om în stare de urs [man in bear shape]"61. They are also called "bersecii" 62 . Hrimnir is "cel care produce chiciura [the one producing slush]"63; Vafprúonirr is "meşterul în ticluieli [the master in plots]" 64 and Ymir is "cel care foşneşte [the rustling one]" 65 or "Hymir, întunecatul [Hymir the dark one]" or even "Androginul [the hermaphrodite]"66. Ymir also appears as Ymer67.

Walhalla appears as "Walholl" and Bifrost simply as "rainbow" but also as "calea cea care se clatină [the way that is shaking]" 68. The name Sigurd is translated as "păzitorul victorios [the victorious guardsmen]" or "cel care aduce pacea prin victorie [the one who brings peace through victory]".

Niflungs are referred to as "copiii ceții [the children of the mist]" in Brot af Sigurparkvipu 69. They also appear as "demonii întunericului [demons of darkness]"70. The analogy has probably been made with Niflheim, "Mist Home", one of the primordial frozen worlds. It is likely

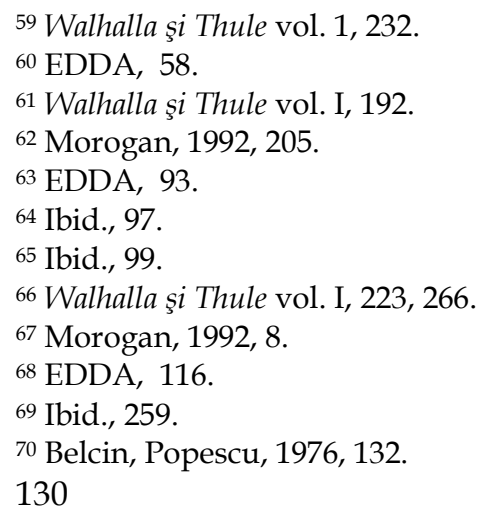


that in this case the word "Nibelungi [Nibelungs]" would be preferred in Romanian (in the meaning "of the Burgundian hoard", not dwarf or other miraculous races). This is the case in Civilizația germanică şi a vikingilor71. In the translation of the Nibelungenlied, "Nibelung" is used alternatively with "burgundy [Burgundian]". Therefore, the hoard or wealth of the Burgundians is referred to as "comoara burgundă [Burgundian treasure]". As an observation, the translation of the Nibelungenlied in Romanian is quite masterful, there are almost no borrowings from Old Germanic or Old Norse, and the text boasts an enormous amount of Romanian archaisms. ${ }^{72}$ Niflheim appears as "țara negurii [the country of mist]" or "țara ghețurilor şi a morții [the country of ice and death]"73 or "tărâmul negurei [mist land]"74.

Skjaldmær/shieldmaidens are mentioned as "fecioare cu scuturi [maidens with shields]".

The primeval cow Auðumbla is, quite strangely, called "Audumla, cea bogată în lichid [Audumbla, the one rich in liquid]", but also "cea lăptoasă [the one full of milk]"75. The variation Audhulma can also be found ${ }^{76}$. Búri, the first god, is also called "cel născut [the born one]". The creature Grendel, Beowulf's enemy, is referred to as "căpcăun [ogre]". Kobolds are described as "pitici sau spiriduşi [dwarves or leprechauns]"77. Ragnarok is unequivocally translated as "amurgul zeilor [the twilight of the gods]" and as "ultima soartă a zeilor [the last fate of the gods]"78. It also appears as "Ragnark"79.

The part of Voluspó describing Ragnarok is translated in many $y^{80}$ Romanian sources:

\footnotetext{
71 Karl Baedeker, Civilizația germanică şi a vikingilor (Prietenii Cărții: Bucureşti, 2006), translation by Liana Gomboşiu.

72 Cântecul Nibelungilor, translation by Claudiu Paradais (Saeculum: Bucharest, 2008).

73 Walhalla şi Thule vol. 1, 232.

74 Boyer, 2002, 130.

75 Walhalla şi Thule vol. 1, 191.

76 Morogan, 1992, 8.

77 Walhalla şi Thule vol. 1, 226.

78 Ibid., 227, 236.

79 Jinga, 2003, 54.

80 Besides the two quite skillful verse interpretations given in the table, it also appears in a type of drápa structure in Belcin, Popescu, 1976, 144.
} 


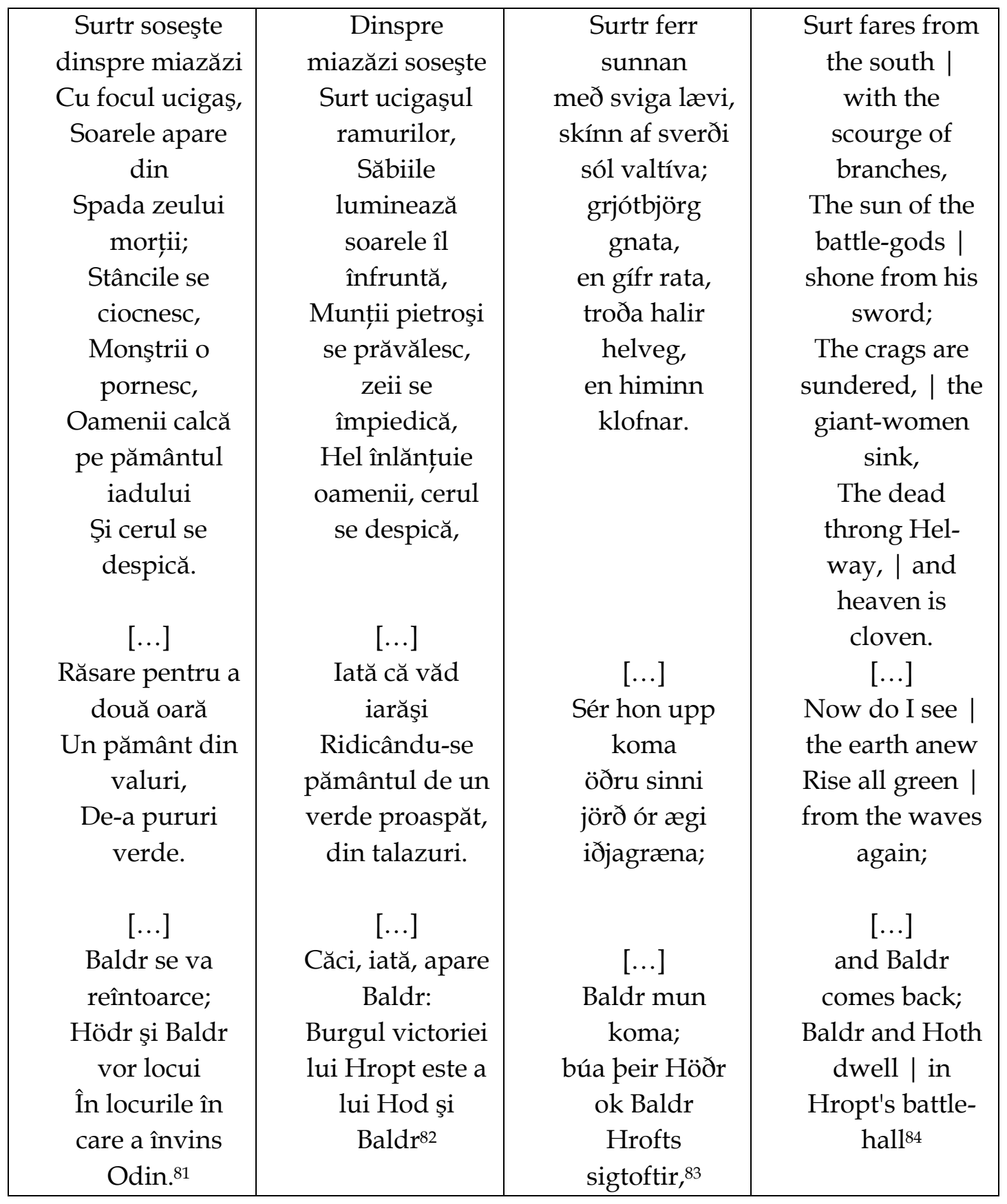

\footnotetext{
81 Baedeker, 2006, 241-242.

82 EDDA, 45-47.

83 Old Norse version from www.voluspa.org.

84 Trans. Henry Adam Bellows, stanzas 52 and parts of 59, 62. 
The dreaded ship Naglfar appears as "corabia din unghii [the ship made of nails]" 85 . The variation Nagelfar may also be found ${ }^{86}$. The enemy, Surt, appears as "Surt/Sutur cel rău/negru [the evil/black one]" 87 or "cel înnegrit de fum [the one blackened by smoke]" 88 .

If we turn our attention to society, there are also some historical terms that prove to be of extreme importance to the current study. Of particularly importance are those terms related to the social classes: jarls, karls and thralls. In the EDDA they appear as thräl, karl, and jarl so the terminology is maintained. In Valhalla şi Thule a few observations are in place dealing with the narration of Rígspula. Thus, here thrall appears as "Thrael sluga [the servant]", karl appears unchanged and Jarl appears as "Iarl”, so the variation is almost insignificant. „Sclav [slave]" is also used for thrall but the author also mentions the inexactitude of this translation by bringing in discussion how difficult it is to find exact equivalents for the Nordic society ${ }^{89}$. Bóndi, the term for a free farmer, appears as "țăranpescar-proprietar liber [free peasant-fisherman-owner]"90. Godi is translated as "preot-sacrificator [sacrificing priest]”.

Saga appears as „poem epic viking [Viking epic poem]” but its secondary meanings of tradition or legend are also given ${ }^{91}$. Skaldic poetry is translated as „poezie skaldă”92. The thing is translated as „instanță [court]" or "parlament local [local parliament]"93. Althing appears as "thing general [the general/universal thing]"94, leid as "thing de toamnă [autumnal thing]" and várthing as "thing de primăvară [spring thing]"95. Drápa is distinguished as being a "type of scaldic poem”, a long series of stanzas usually including a refrain, and is opposed to flokkr, which does not have a refrain. A comparison of the translation of stanzas 77 and 78 of Họvamọ́l, dealing with the eternal importance of honor and prestige in

\footnotetext{
85 Walhalla şi Thule vol. I, 231.

86 Morogan, 1992, p. 42.

87 Walhalla şi Thule vol. I, 244.

88 Boyer, 2002, 124.

89 Ibid., 27.

90 Ibid., 257.

91 Belcin, Popescu, 1976, 129.

92 Ibid.

93 Boyer, 2002, 29.

94 Ibid., 257.

95 Ibid., 260.
} 
Viking society, is very interesting for the present study (notable differences are marked in square brackets):

\begin{tabular}{|c|c|c|}
\hline EDDA, 134 & $\begin{array}{l}\text { Islanda medievală, } \\
104\end{array}$ & $\begin{array}{l}\text { Henry } \quad \text { Adams } \\
\text { Bellows' translation }\end{array}$ \\
\hline $\begin{array}{l}\text { Vitele mor, rudele } \\
\text { se sting din viață, }\end{array}$ & $\begin{array}{l}\text { Mor averile [wealth } \\
\text { perishes], moare } \\
\text { rudenia, }\end{array}$ & $\begin{array}{l}\text { Cattle die, and } \\
\text { kinsmen die, }\end{array}$ \\
\hline $\begin{array}{l}\text { La rândul tău şi tu } \\
\text { eşti muritor; }\end{array}$ & $\begin{array}{l}\text { Şi tu vei muri de } \\
\text { asemenea; }\end{array}$ & $\begin{array}{l}\text { And so one dies } \\
\text { one's self; }\end{array}$ \\
\hline $\begin{array}{l}\text { Dar renumele } \\
\text { [renown] nu se } \\
\text { poate stinge } \\
\text { niciodată, } \\
\text { Dobândit în timpul } \\
\text { trecătoarei vieți.96 }\end{array}$ & $\begin{array}{l}\text { Dar există ceva } \\
\text { Care niciodată nu } \\
\text { moare } \\
\text { Faima (ordstirr) [the } \\
\text { fame] pe care ai } \\
\text { câştigat-o. }\end{array}$ & $\begin{array}{l}\text { But a noble name } \\
\text { will never die, } \\
\text { If good renown one } \\
\text { gets. }\end{array}$ \\
\hline $\begin{array}{l}\text { Vitele mor, rudele } \\
\text { se sting din viață, } \\
\text { La rândul tău şi tu } \\
\text { eşti muritor; }\end{array}$ & $\begin{array}{l}\text { Mor averile [wealth } \\
\text { perishes], mor } \\
\text { părinții } \\
\text { Şi tu vei muri. }\end{array}$ & $\begin{array}{l}\text { Cattle die, and } \\
\text { kinsmen die, } \\
\text { And so one dies } \\
\text { one's self; }\end{array}$ \\
\hline $\begin{array}{l}\text { Un lucru ştiu sigur, } \\
\text { care trăieşte veşnic; } \\
\text { Aura cu care s-a } \\
\text { încununat [the } \\
\text { earned aura] mortul } \\
\text { pe timpul vieții. }\end{array}$ & $\begin{array}{l}\text { Dar ceva } \\
\text { Nu va muri } \\
\text { nicicând: } \\
\text { Cuvintele rostite } \\
\text { [the said words] } \\
\text { despre fiecare mort. }\end{array}$ & $\begin{array}{l}\text { One thing now that } \\
\text { never dies, } \\
\text { The fame of a dead } \\
\text { man's deeds. }\end{array}$ \\
\hline
\end{tabular}

There are no differences in the understanding of these texts even though the first one is translated from German and the second one from

96 This first stanza is also translated in Belcin, Popescu, 1976, 151. 
French, save that on different occasions both translators have preferred metaphors to common expressions ("cattle" vs. "wealth" vs. "cattle”; or "the earned aura" vs. "the said words" vs. "the fame") .

Civilizația germanică (85) also contains some valuable saga fragments that may be useful for comparisons, which is given below with an English translation:

1 Theodoric ${ }^{97}$ a domnit 1 Pjóðríkr hinn 1 Pjóðríkr the bold, 2 prințul războinicilor pormóði,

3 Cu scutul la umăr 2 stillir flotna, 2 chief of sea-warriors,

4 el călăreşşte acum,

6 strǫndu Hreiðmarar.

6 ruled over the shores

5 inima dârză,

5 Sitr nú gơrr of the Hreiðsea.

odinioară,

4,7 á gota sínum,

6 pe plajele Nidului.

3 skildi umb fatladr,

5 Now he sits armed

7 călare pe calul său,

8 culmea muritorilor ${ }^{98}$.

8 skati Mæringa

4,7 on his Goth(ic

horse),

3 his shield strapped,

8 the prince of the Mærings.

The above fragment, presented in its source as a part of the Edda, is part of the inscription of the famous Rök Runestone. The original topic has been changed in the Romanian translation, as this can be seen by numbering the Romanian verses and their corresponding originals. Still, the beginning, ending and middle remain the same, as it can be noticed. One might wonder why was the Hreiðsea interpreted as the Nid river in Romanian.

A fragment about Egil is given at page 123 of the translated Civilizatia germanică and deals with Egill Skallagrimssonn:

Senin şi puternic,

Fără lacrimi, fără frică, Bucuros aşteaptă Moartea. skal ek pó glaðr með góðan vilja ok óhryggr
I shall, glad and unconcerned and with good-will await death

97 The king of the Ostrogoths.

${ }_{98}$ A metaphor for king. 
heljar bíða. ${ }^{99}$

Another translated fragment of a saga probably belongs to Kormak's saga ${ }^{100}$ :

Tunetul se aude deasupra mării

Munții de valuri sunt uriaşi

Oceanul mugind

Se azvârle asupra noastră
Brimgnýr, brattir

hamrar

blálands

Haka

strandar.
Surf on a rock-bound shore of the sea-king's blue domainLook how it lashes the crags, hark how it thunders again!

The following fragment of the important lay Krákumál, the death song of Ragnarr Loðbrók, is also translated into Romanian, but no English translation could be identified for this 25 th(?) stanza of the lay 101 :

Am lovit cu spada.

Mă bucur să ştiu că

Odin e pregătit de ospăt,

Vom bea în curând

Bere din pocale.

Moartea nu-l apasă pe cel curajos

Din palatul lui Odin.

Eu m-am adăpostit sub acoperişul

Năvalnicului neînfricat...
We swung our

swords,

Glad am I to know

that

Odin is ready for a

feast

We will soon drink

Beer in our cups

Death does not press

on the brave one

In Walhalla,

I have come under the protection
Hjoggum vér með hjörvi.

Hitt lœgir mik, jafnan at Baldrs föður bekki

búna veitk at sumblum.

Drekkum bjór af bragði

ór bjúgviðum hausa;

sýtira drengr við

dauða

dýrs at Fjölnis húsum;

eigi kømk með æðru

\footnotetext{
${ }^{99}$ It is a part of Sonatorrek (Loss of Sons) by Egil. Taken from the English prose translation and glosses by Bjarni Einarsson, from Egils saga (London: Viking Society for Northern Research, 2003) 146-154.

100 Found in Baedeker, 2006, 127. English, transl. W.G. Collingwood and J. Stefansson, from the original 'Kormáks saga'.

101 Baedeker, 2006, 133.

136
} 
Heimskringla has not been entirely left aside by Romanian translators. The impressive account of the burning of Hedeby/Heiðabýr is given as follows:

De la un colt la altul

Hedeby a ars.

Ingrozitoare

Furie a bătăliei.

Impunătoare

Pare întâmplarea. Cred că

Sven Irascibilul se supără.

Înainte de crespuscul încă,

Am pus piciorul în piață.

Am pus piciorul în piață:

Flăcări înalte izbucneau din acoperişuri... 103
Brenndr var upp með endum allr, en pað má kalla hraustlegt bragð, er eg hugði, Heiðabær af reiði. Von er að vinnum Sveini, vask í nótt fyr óttu, gaus hár logi úr húsum, harm, á borgararmi. ${ }^{104}$
All Heidaby is
burned down!
Strangers will ask
where stood the
town.

In our wild humour up it blazed, And Svein looks round him all amazed.

All Heidaby is burned down! From a far corner of the town

I saw, before the peep of morning, Roofs, walls, and all in flame high burning. ${ }^{105}$

The same fragment above also appears in prose in Romanian: "Ars era Haithabu de la un capăt la altul. A fost o treabă pentru care Swein va suferi. Înalt se ridicau flăcările din case, în ultima noapte, înaintea zorilor, eu am stat pe valul fortăreței"106. There is little to almost no difference in meaning between the verse and the prose versions.

\footnotetext{
102 Translated into English from Romanian by the author of the article, unfortunately it is not clear which stanza of Krákumál is this, but stanza 25 appears to be the closest one.

103 Baedeker, 2006, 162.

${ }^{104}$ Icelandic, taken from Snorri Sturlson's Heimskringla.

105 Douglas B. Killings, Snorri Sturlson, Heimskringla (1996).

106 Belcin, Popescu, 1976, 91.
} 
The oldest runic verses (on the Tune and Stentoften runestones) have also been translated to Romanian:

\begin{tabular}{|ccc|}
\hline $\begin{array}{c}\text { Eu, Wiw de lângă } \\
\text { Wodurid }\end{array}$ & Ek Wiwaz after & I, Wiwaz, made the \\
Wăstrătorul pâinii, & witandahlaiban & runes \\
$\begin{array}{c}\text { Am gravat aceste } \\
\text { rune. }{ }^{107}\end{array}$ & worhto r[unoz] & my lord \\
\hline
\end{tabular}

\begin{tabular}{|c|c|c|}
\hline $\begin{array}{l}\text { Noilor veniți, } \\
\text { Noilor vecini, } \\
\text { Hathawolf le } \\
\text { spune un an bun, }\end{array}$ & $\begin{array}{l}<\text { niuha>borumz } \\
<\text { niuha>gestumz } \\
\text { Hapuwulfz gaf } \mathrm{j}[\mathrm{ar}], \\
\text { Hariwulfz ... } \\
\text { haidiz runono, felh } \\
\text { eka hedra }\end{array}$ & $\begin{array}{l}\text { (To the) } \\
<\text { niuha }>\text { dwellers } \\
\text { (and) < niuha>guests } \\
\text { Hapuwulfar gave ful } \\
\text { year, } \\
\text { Hariwulfar ... ... I, } \\
\text { master of the } \\
\text { runes(?) conceal here }\end{array}$ \\
\hline [missing part?] & & nine bucks, nine \\
\hline $\begin{array}{l}\text { Să poată } \\
\text { Hariwolf } \\
\text { îndepărta răul. }\end{array}$ & $\begin{array}{l}\text { niu habrumz, niu } \\
\text { hangistumz } \\
\text { Hapuwulfz gaf } j[a r],\end{array}$ & $\begin{array}{l}\text { stallions, } \\
\text { Hapuwulfar gave } \\
\text { fruitful } \\
\text { year, }\end{array}$ \\
\hline $\begin{array}{l}\text { Ascund aici, } \\
\text { runele puternice, }\end{array}$ & $\begin{array}{l}\text { Hariwulfz } \ldots \\
\text { haidiz runono, felh } \\
\text { eka hedra }\end{array}$ & $\begin{array}{l}\text { Hariwulfar ... ... I, } \\
\text { master of the } \\
\text { runes(?) conceal here }\end{array}$ \\
\hline $\begin{array}{l}\text { Un şir de rune } \\
\text { splendide. }\end{array}$ & ginn & run \\
\hline Sortit morții & & Incessantly (plagued \\
\hline Fie acela & $\begin{array}{l}\text { Hermalausaz argiu, } \\
\text { Weladaups, sa pat }\end{array}$ & $\begin{array}{l}\text { by) maleficence, } \\
\text { (doomed }\end{array}$ \\
\hline $\begin{array}{ll}\text { Care le } & \text { le } \\
\text { distruge. }{ }^{108}\end{array}$ & briutip & $\begin{array}{l}\text { insidious death (is) } \\
\text { he who this }\end{array}$ \\
\hline
\end{tabular}

107 Baedeker, 2006, 219.

108 Ibid. 
breaks. ${ }^{109}$

As seen above, a part of the Stentoften rune stone inscription is missing ("nine bucks, nine stallions"). A part of the song of the Valkyries is also translated:

\begin{tabular}{|c|c|c|}
\hline $\begin{array}{l}\text { Noi țesem, noi } \\
\text { țesem }\end{array}$ & $\begin{array}{l}\text { Vindum, vindum } \\
\text { vef darraðar }\end{array}$ & $\begin{array}{l}\text { Wind we, wind we } \\
\text { the web-of-darts }\end{array}$ \\
\hline Pânza & par er vé vaða & where float the flags \\
\hline stindardelor... & vígra manna. & of unflinching men! \\
\hline Să nu lăsăm viața & Látum eigi & Let not the lieges \\
\hline Să ne scape & liff hans farast, & life be taken: \\
\hline $\begin{array}{l}\text { Walkiriile } \\
\text { dreptul }\end{array}$ & $\begin{array}{l}\text { eiga valkyrjur } \\
\text { vals um kosti. }{ }^{111}\end{array}$ & $\begin{array}{l}\text { valkyries award the } \\
\text { weird of battle. }{ }^{112}\end{array}$ \\
\hline $\begin{array}{l}\text { Să-şi } \\
\text { morții. }{ }^{110}\end{array}$ & & \\
\hline
\end{tabular}

A part of the the Gripsholm runestone is also translated in F. Durand, Vikingii (55):

\begin{tabular}{|l|c|r|}
\hline $\begin{array}{l}\text { Au plecat cu } \\
\text { bărbăție foarte } \\
\text { departe în căutarea }\end{array}$ & $\begin{array}{c}\text { PæiR foru drængila } \\
\text { fiarri at gulli ok } \\
\text { austarla ærni gafu, } \\
\text { aurului şi acolo }\end{array}$ & $\begin{array}{r}\text { They travelled } \\
\text { valiantly far for } \\
\text { gold, and in the } \\
\text { către răsărit au }\end{array}$ \\
$\begin{array}{l}\text { dou sunnarla a } \\
\text { hrănit vulturul }\end{array}$ & $\begin{array}{r}\text { east gave (food) to } \\
\text { the eagle. (They) } \\
\text { duşmanilor lor şi }\end{array}$ \\
$\begin{array}{l}\text { au murit la miazăzi } \\
\text { in ținutul mătăsii. }\end{array}$ & & $\begin{array}{r}\text { Serkland. } \\
\text { din the south in }\end{array}$ \\
\hline
\end{tabular}

The introductory part (stanzas 2 and 3) of the Lay of Hindla appear in two Romanian translations:

\footnotetext{
109 The Proto-Norse inscriptions and their translations have been taken from Runedata (N KJ72 U, DR 357).

110 Baedeker, 2006, 218.

111 Njáls saga, chapter 157.

112 Lee M. Hollander, Old Norse Poems (London: Abela Publishing, 2010), 145.
} 


\begin{tabular}{|c|c|c|c|}
\hline $\begin{array}{l}\text { Să implorăm } \\
\text { îndurarea } \\
\text { Părintelui } \\
\text { Armatelor! } \\
\text { El împarte cu } \\
\text { dărnicie aurul } \\
\text { oamenilor săi; } \\
\text { El i-a dat lui } \\
\text { Hermod un } \\
\text { coif şi o platoşă } \\
\text { Şi lui Sigmund } \\
\text { i-a dăruit o } \\
\text { spadă. } \\
\text { Unora le dă } \\
\text { victoria, } \\
\text { Altora bogăți, } \\
\text { Multora le dă } \\
\text { elocință şi } \\
\text { inteligență } \\
\text { Eroilor mărilor } \\
\text { le dă vânt } \\
\text { favorabil; } \\
\text { Scalzilor le dă } \\
\text { darul poeziei, } \\
\text { Multor } \\
\text { războinici le dă } \\
\text { putere şi } \\
\text { curaj...113 }\end{array}$ & $\begin{array}{l}\text { Hai să-l rugăm } \\
\text { pe părintele } \\
\text { oastei, să ne } \\
\text { arate } \\
\text { bunăvoința sa, } \\
\text { El, care } \\
\text { dăruieşte cu } \\
\text { plăcere aurul } \\
\text { lui suitei sale; } \\
\text { Lui Hermod i- } \\
\text { a dat coiful şi } \\
\text { armura, } \\
\text { O sabie tăioasă } \\
\text { îi dărui lui } \\
\text { Sigmund. } \\
\text { Unuia i-a dat } \\
\text { victoria, } \\
\text { celuilalt } \\
\text { comori, } \\
\text { Multă } \\
\text { înțelepciune şi } \\
\text { o vorbă aleasă; } \\
\text { Marinarului - } \\
\text { vânt prielnic, } \\
\text { cântărețului - } \\
\text { arta poeziei, } \\
\text { Forță fizică - } \\
\text { unor eroi.114 }\end{array}$ & $\begin{array}{l}\text { Gefr hann sigr } \\
\text { sumum, } \\
\text { en sumum } \\
\text { aura, } \\
\text { mælsku } \\
\text { mörgum } \\
\text { ok mannvit } \\
\text { firum; } \\
\text { byri gefr hann } \\
\text { brögnum, } \\
\text { en brag } \\
\text { skaldum, } \\
\text { gefr hann } \\
\text { mannsemi } \\
\text { mörgum } \\
\text { rekki.115 }\end{array}$ & $\begin{array}{l}\text { The favor of } \\
\text { Heerfather | } \\
\text { seek we to } \\
\text { find, } \\
\text { To his } \\
\text { followers gold } \\
\text { | he gladly } \\
\text { gives; } \\
\text { To Hermoth } \\
\text { gave he | helm } \\
\text { and mail-coat, } \\
\text { And to } \\
\text { Sigmund he } \\
\text { gave | a sword } \\
\text { as gift. } \\
\text { Triumph to } \\
\text { some, | and } \\
\text { treasure to } \\
\text { others, } \\
\text { To many } \\
\text { wisdom | and } \\
\text { skill in words, } \\
\text { Fair winds to } \\
\text { the sailor, | to } \\
\text { the singer his } \\
\text { art, } \\
\text { And a manly } \\
\text { heart | to } \\
\text { many a hero.116 }\end{array}$ \\
\hline
\end{tabular}

\footnotetext{
113 Baedeker, 2006, 234.

114 EDDA, 157.

115 Guðni Jónsson's edition of Hyndluljóð.

116 Transl. Henry Adam Bellows, the Poem of Hyndla. 
Another fragment, a stanza of Griplur (III, 29), is translated in Islanda Medievală (207):

\begin{tabular}{|c|c|c|}
\hline Iată că a venit & Nu mun råb ab fara & Lo that time has \\
vremea să ne & å fætr, & come to get ready \\
pregătim, & frýr pú hugarins & To defy the \\
Să sfidăm curajul & draugi, & boldness of the \\
strigoiului, & dagrinn lidur & undead, \\
Ziua se îndreaptă & drjúgt til nœetr, & The day will soon \\
curând către & dimma tekr i haugi & turn into night, \\
noapte, & & Darkness falls over \\
Intunericul se lasă & & the hill 117 \\
pe deal & & \\
\hline
\end{tabular}

As far as rulers are concerned, Haraldr Hárfagri's nickname (Fairhair) the king of Norway is translated as ,cel cu Păr Frumos [the one with beautiful hair]"118 but also "cel cu plete frumoase [the one with beautiful locks]"119 or simply "păr frumos"120. His father, Halfdanr Svarti, appears as Halfdan "cel Negru [the Black]"121. King Ólafr Haraldsson also appears as "cel Gros [the Stout]". One can also find Harald Hardraade ${ }^{122}$ but also Hardrada, Erik I Bloodaxe appears as "Secure Însângerată [bloody axe]", Olaf but also Olav Trygvasson ${ }^{123}$, Ari Thorgilson is called "Învățatul [the learned one]"124, there is Svein but also Svend Estrithson/Estridsson, Knud, Cnut, Knut and Canute I „cel Mare [the Great]”125. Rollo is also called Robert I ${ }^{126}$. Saemund appears as „Saemund cel Înțelept [the Wise]"127. Harald Bluetooth's nickname is translated as

\footnotetext{
117 Translated into English from Romanian by the author of the article.

118 Belcin, Popescu, 1976, 131.

119 Boyer, 2002, 24.

120 F. Donald Logan, Vikingii în istorie, translation by Mariana Grancea (Editura Bălcescu: Bucureşti, 1990), 22.

${ }^{121}$ Belcin, Popescu, 1976, 28.

122 Donald, 1990, 25.

123 Ibid., 36.

124 Ibid., 72.

125 Ibid., 96.

126 Belcin, Popescu, 1976, 159.

127 Ibid., 160.
} 
"Dinte Albastru" in the great majority of sources. The Norman adventurer William Iron Arm appears as „Wilhelm Braț de Fier, Dragon [Iron Arm, Dragon]"128. It is interesting that Hedeby/Haithabu is translated as "oraşul de pe câmpiile cu buruieni [the city on the field with weeds]"129. Ingjald illråde is translated into Romanian as „Ingljad cel Rău [Ingljad the Evil]"130. Eric/Erik cel Roşu [the Red] is the Viking leader that is found in most of the Romanian sources, no matter if the major subject is mythological or historical. Vilhjálmr Langaspjót (William I Longsword) appears as "Guillaume Spadă Lungă"131. The choice of Guillaume over the almost omnipresent Wilhelm in Romanian historiography is explainable since the translator has worked with a French source.

\section{Conclusion}

A conclusion that could be deduced from the above chosen examples of Romanian translated key concepts relating to the Old Norse civilization is that the closer the translations are to our times the more open to borrowing and thus the more exact they are. As stated in the beginning, I have considered the 2005 translated Edda as a standard in comparison to other works because it represents the fundamental writing of this civilization. Most works written before 1990 show an attachment to the vocabulary of Romanian early Middle Ages or of folk tales, including fictional works such as translations of Beowulf or the Nibelungenlied. For the latter, the same vocabulary is also maintained for more recent simplified translations in prose. There have been rare cases when Romanian characters such as the schwa (“ă”) have been intermixed with Germanic names or terms, creating interesting hybrids. Regarding the abundant poetic works of the Viking age, a certain preference has been noticed for the translation of fragments detailing Ragnarök, owning to the preference of Western authors used as sources for these fragments in their own works. Of all elements of Nordic mythology, the most problematic for Romanian translators has proven to be the Elves. The loanword

\footnotetext{
128 Ibid., 57.

129 Ibid., 90.

130 Ibid., 131.

131 Durand, 2003, 39.

142
} 
"elfi"132 has only recently, in the past few years, made its full entry into the Romanian vocabulary probably due to the great popularity 133 of the works of J. R. R. Tolkien (the educated younger Romanian public is well acquainted with the translations of The Lord of the Rings, Silmarillion to a lesser exten, and The Hobbit). The confusion between elves and dwarves/gnomes is omnipresent in Romanian sources. The most fascinating expressions translated into Romanian are those dealing with the multiple names of Odin, which of course is a consequence of the richness of the imagination of the Old Norse. On the same note, the entire subject of researching the vocabulary of the ample Nordic civilization in a Southern European language is equally thought-provoking and curious.

\section{References:}

Cântecul nibelungilor. Editura de Stat pentru Literatură şi Artă: Bucureşti, 1958. Verse adaptation by Adrian Maniu.

Cântecul Nibelungilor. Saeculum: Bucharest, 2008. Translation by Claudiu Paradais.

Edda. Bucureşti: Saeculum I.O., 2005. Translation by Magda Petculescu, Foreword by Dan Grigorescu.

Egils Saga. London: Viking Society for Northern Research, 2003. Edited by Bjarni Einarsson.

The Poetic Edda. Two Volumes in One. Princeton University Press: Princeton, 1936. Translated with Introduction and Notes by Henry Adams Bellows.

Walhalla şi Thule. Mituri şi legende vechi germanice. Vol. 1, 2. Editura Minerva: Bucureşti, 1977. Readaptation by Mihai Isbăşescu.

Baedeker, Karl. Civilizația germanică şi a vikingilor. Prietenii Cărții: Bucureşti, 2006. Translation by Liana Gomboşiu.

Belcin, Cornelia. Popescu, Alexandru. Vikingii. Albatros: Bucureşti, 1976.

\footnotetext{
132 The fact that in the DEX (Romanian Explicative Dictionary published under the auspices of the Romanian Academy) it is said that the Elves are imagined as "pitici [dwarves/gnomes]" has certainly not helped clear this confusion.

133 One needs only to enter the keyword "Tolkien" on any Romanian search engine to realize this. The keyword "Tolkien Romania" returns over 1,000,000 results.
} 
Bengtsson, Frans G. Vikingii. O povestire istorică din vremurile străbune. Dacia: Cluj, 1974. Translation by Constantin A. Gâdei.

Boyer, Régis. Islanda medievală. Vikingii. ALL: Bucureşti, 2002.

Durand, Frédéric. Vikingii. Corint: Bucureşti, 2003. Translation by Ovidiu Cristea.

Hollander, Lee M. Old Norse Poems. London: Abela Publishing, 2010.

Jinga, Cristina. Comorile Nibelungilor. Prietenii Cărții: Bucureşti, 2003.

Logan, F. Donald, Vikingii în istorie. Editura Bălcescu: Bucureşti, 1990. Translation by Mariana Grancea.

Lorint, Florica. Oamenii nordului. Editura Ştiințifică: Bucureşti, 1965.

Morogan, Elena-Maria. Mitologia Nordică. Mituri şi legende. Editura Enciclopedică: Bucureşti, 1992.

Sturlson, Snorri. Heimskringla or the Chronicles of the Kings of Norway. 1996. Edited, proofed, and prepared by Douglas B. Killings.

\section{On-line sources}

The poetic Edda in Old Norse and English, http://www.voluspa.org/, accessed 5 April 2013.

Scandinavian

Runic-text

Data

Base,

http://www.nordiska.uu.se/forskn/samnord.htm, accessed 3 April 2013. 